\title{
Reproductive traits and natural mortality of the cardinalfish Epigonus crassicaudus: crucial information for stock assessment and sustainable management measures
}

\author{
Guillermo Moyano ${ }^{1,2}$, Francisco Cerna ${ }^{1}$, Elson Leal ${ }^{1}$, Guido Plaza $^{2}$ \& Vilma Ojeda ${ }^{1}$ \\ ${ }^{1}$ División de Investigación Pesquera, Instituto de Fomento Pesquero (IFOP), Valparaíso, Chile \\ ${ }^{2}$ Escuela de Ciencias del Mar, Pontificia Universidad Católica de Valparaíso, Valparaíso, Chile \\ Corresponding author: Guillermo Moyano (guillermo.moyano@ifop.cl)
}

\begin{abstract}
Reproductive traits and natural mortality rate of cardinalfish females (Epigonus crassicaudus) were studied from samples collected onboard commercial fishing vessels, from 2012 to 2015, on the Chilean coast. The reproductive cycles of females analyzed thought gonadosomatic index (GSI) showed a maximum reproductive activity in austral fall, between March and May. Length $\left(\mathrm{L}_{50 \%}\right)$ and age $\left(\mathrm{A}_{50 \%}\right)$ at maturity, estimated using a macroscopic scale of the developed ovary, was $22.3 \mathrm{~cm}$ fork length (FL) and 9.3 years, respectively. Natural mortality $(M)$ was estimated by two age-related methods. Using maximum age $\left(\mathrm{t}_{\max }\right) \mathrm{M}$ was estimated in $0.063 \mathrm{yr}^{-1}$ and through age-at-maturity $\left(\mathrm{A}_{50 \%}\right)$ in $0.15 \mathrm{yr}^{-1}$. A potential bias in the reproductive study is discussed when a macroscopic maturity scale is used. Nevertheless, its usefulness is validated when funding is scarce, and time is limited. Although M uncertainty was not evaluated, the estimated range appears to be into the expected values to long-lived species. The life history parameters estimated in the present study can be used to evaluate possible time variability in maturity and $\mathrm{M}$ rates. Also, these results could be used in stock assessment analysis and to apply effective management measures in the fishery.
\end{abstract}

Keywords: Epigonus crassicaudus; maturity; reproduction; natural mortality; fishery

\section{INTRODUCTION}

Information on reproduction and natural mortality (M) is very important to properly manage the exploitation of fisheries resources (Charnov \& Berrigan, 1991; Rose et al., 2002; Winker et al., 2011). Revealing the reproductive cycle and length or age-at-maturity provides insight that can help to enable necessary management measures (Jakobsen et al., 2009). Also, M is one of the most influential parameters in fisheries stock assessment and management (Wang \& Ellis, 2004; Brodziak et al., 2011).

The cardinalfish (Epigonus crassicaudus) (De Buen, 1959) belongs to the Epigonidae family, a poorly studied group of perciform fishes, with permanent records of new species (Okamoto \& Motomura, 2011; Okamoto et al., 2011). This species is endemic along the Chilean coast, distributed mainly between $29^{\circ} 00^{\prime} \mathrm{S}$ and $42^{\circ} 50^{\prime} \mathrm{S}$, in depths between 100 and $500 \mathrm{~m}$ (Wiff et al., 2005; Leal et al., 2009). Cardinalfish landings ha- ve been recorded since 1992 with $579 \mathrm{t}$ at that year, its peak in landings was 5,792 $\mathrm{t}$ recorded in 2000 (SERNAPESCA, 2000). Today, due to over-exploitation, the fishery is closed, and the government only authorized bycatch of 2 and $12 \mathrm{t}$ for the artisanal and industrial fleets, respectively (SUBPESCA, 2016).

Regarding its biology, some studies addressing the food and trophic levels of this species have been reported (e.g., Arancibia \& Meléndez, 1987; Neira \& Arancibia, 2004; Leal et al., 2009; Sepúlveda et al., 2018). Also, the annual reproductive cycle and maturity in length to females was reported by Flores et al. (2015). However, to date, there not published information on natural mortality (M) for $E$. crassicaudus; nevertheless, technical reports (Cubillos et al., 2009; Tascheri \& Flores, 2013) have suggested low values to this parameter due to low growth rates and a potential long-life span. Moreover, Moyano et al. (2018) pointed E. crassicaudus as a slow-growing species and with a life span of about 67 years. This spe-

Corresponding editor: Alejandra Volpedo 
cies is especially vulnerable to overfishing during recruitment, due to removing the larger individuals can favor slower growing and earlier of maturing fishes (Ziegler et al., 2007; Cailliet \& Andrews, 2010).

The recovery of catches of cardinalfish depends on management measures, based on reliable biological background. Hence, information on life-history parameters is crucial for this purpose. Thus, considering, both reproduction and $\mathrm{M}$ rates are critical parameters for stock assessment and management because they are important predictors of the risk of overexploitation (Clark, 1991; Reynolds et al., 2005), the current study examined annual reproductive cycle, length and age at maturity and M rates E. crassicaudus for 2012 to 2015 period.

\section{MATERIALS AND METHODS}

\section{Reproduction}

A total of 4,214 fishes were collected monthly between January 2012 and December 2015, covering an area located between $34^{\circ} 50^{\prime} \mathrm{S}$ and $39^{\circ} 00^{\prime} \mathrm{S}$ off the Chilean coast (Fig. 1). Samples were collected randomly during bottom trawls on board of commercial fishing vessels, registering sex, fork length (FL, cm), total weight (TW, $\mathrm{g})$, ovary weight (OW, g) and gutted weight $(\mathrm{GW}, \mathrm{g})$. Sagittae otoliths were extracted, dried and stored in paper envelopes and carefully labeled to ensure traceability. Then, in the laboratory, age in years of each specimen was assigned on otoliths transversal sections according to the criteria described by Ojeda $e t$ al. (2010) and Moyano et al. (2018). Ovary of each female was classified into six stages, according to macroscopic maturity scale (Balbontín \& Bravo, 1993), virginal (1), immature (2), maturation (3), mature (4), mature with recent spawning (5) and regressing (6). The annual reproductive cycle for female cardinalfish was characterized by assessing the monthly gonadosomatic index (GSI) variation (Nikolsky, 1963), using a total of 2,812 ovaries according to:

$$
I G S=(O W / G W) \times 100
$$

where OW is the ovary weight ( $\mathrm{g}$ ) and GW is gutted weight $(\mathrm{g})$.

Length and age-at-maturity for females were determined using selected data, collected in the main reproductive season of each year, considering a total of 796 samples. Females that had reached at least stage 3 in the macroscopic maturity scale were classified as mature. The proportion of mature fish at length and age was fitted using a logistic function (Schnute \& Richards, 1990):

$$
P m=1 /\left(1+e^{(\alpha+\beta \times X)}\right)
$$

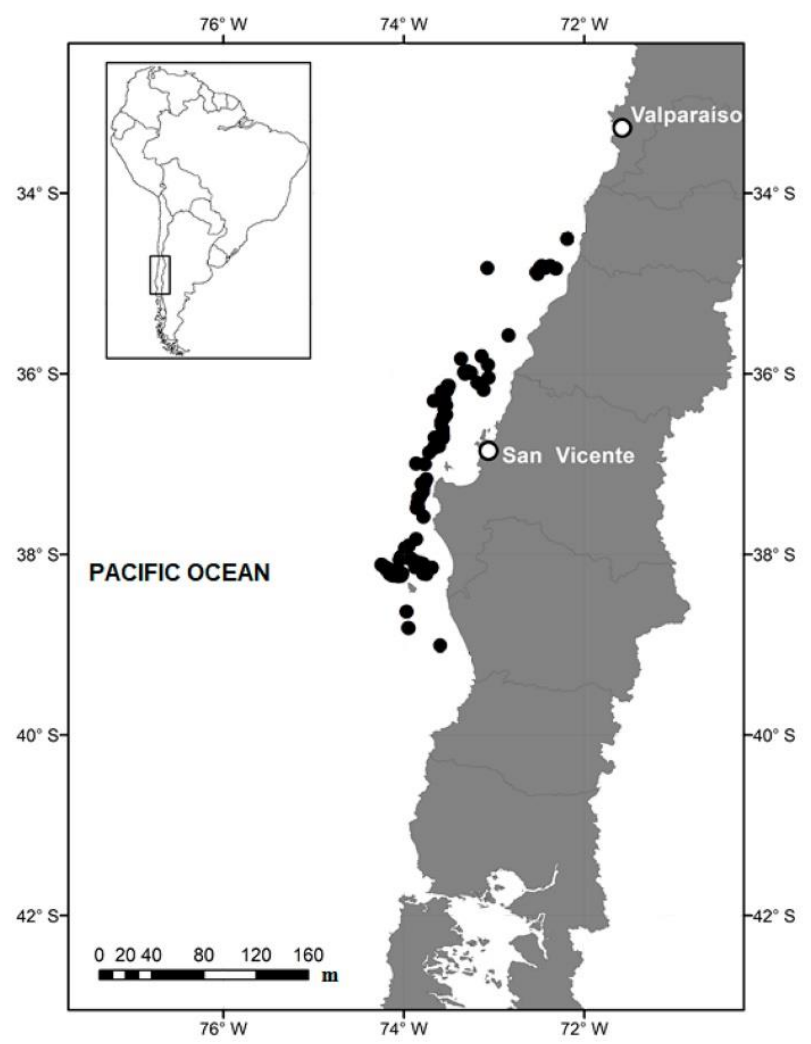

Figure 1. Spatial distribution of cardinalfish Epigonus crassicaudus hauls throughout the fishery area for the period 2012-2015.

where $P m$ is the proportion of mature adult fish of length or age (X), and $\alpha$ and $\beta$ are parameters estimated by least squares with a binomial error distribution. The length or age at which $50 \%$ of individuals are estimated to be adult mature ( $\mathrm{L}_{50 \%}$ and $\mathrm{A}_{50 \%}$ ) was calculated based on the work by Roa et al. (1999):

$$
L_{50}, A_{50}=-\alpha / \beta
$$

\section{Natural mortality}

Two approaches as a function of maximum age $\left(t_{\max }\right)$ and maturity age $\left(\mathrm{A}_{50 \%}\right)$ were used to estimate the natural mortality rate $(\mathrm{M})$.

1) The model of Rikher \& Efanov (1976), as follows:

$$
M=\left[\frac{1.521}{t_{m 50 \%}^{0.72}}\right]-0.155
$$

where $t^{0.72} m_{50 \%}$ is $50 \%$ of mature females estimated in the present study $\mathrm{A}_{50 \%}$.

2) The model of Hewitt \& Hoenig (2005) as:

$$
M=\frac{4.22}{t_{\max }}
$$

where $t_{\max }$ corresponds at the maximum estimated age in this species (Moyano et al., 2018). 


\section{RESULTS}

\section{Reproduction}

The annual reproductive cycle evaluated through monthly IGS variation to females analyzed between 2012 and 2015, showed a possible reproductive rest in austral spring and summer from August to December with a low index value. A maximum IGS in fall (March, April and May) would be indicating a more intense reproductive activity for the population (Fig. 2). For this period, females analyzed to maturity study in length and age ranged from 15 to $38 \mathrm{~cm} \mathrm{FL,}$ corresponding to specimens between 4 and 67 years.

In terms of length, the logistic model showed a fast maturity process between 18 and $25 \mathrm{~cm}$ FL. The mean $\mathrm{L}_{50 \%}$ was estimated in $22.3 \mathrm{~cm}$ FL (Fig. 3) from parameters $\alpha=15.71(\mathrm{SE}=3.42 ; P>0.05)$ and $\beta=$ $-0.71(\mathrm{SE}=0.15 ; P>0.05)$ respectively. Probably due bias in assignment of maturity stages observed data not showed a clear length to full population maturity $\left(\mathrm{L}_{100 \%}\right)$. Nevertheless, fitted models suggest $28 \mathrm{~cm} \mathrm{LF}$.

The maturity age with parameters $\alpha=4.68$ ( $\mathrm{SE}=$ $1.42 ; P>0.05)$ and $\beta=-0.50(\mathrm{SE}=0.14 ; P>0.05)$, indicate $\mathrm{A}_{50 \%}$ for female Epigonus crassicaudus to be 9.3 years. Females analyzed showed an active maturity process in individuals over six years; samples from this age showed the first maturity signals. Observed data and fitted models showed a high probability of a full maturity population from 14 years.

\section{Natural mortality}

Considering the parameters $t_{\max }=67$ years, which corresponded to the maximum estimated age, the natural mortality rate was $0.063 \mathrm{yr}^{-1}$ and with the method based on age-at-maturity $\left(\mathrm{A}_{50 \%}=9.3\right.$ years $)$ resulted in $0.15 \mathrm{yr}^{-1}$.

\section{DISCUSSION}

The reproductive cycle showed a period of reproductive maximization from March to May and in resting between august and December. These results are partially coincident with the unique study published before in the reproductive biology of Epigonus crassicaudus. Flores et al. (2015) showed the occurrence of permanent vitellogenesis through the year, although identified through GSI, a reproductive peak between May and June. Hence, the results of the current study confirm the spawning season for this species to be concentrated in austral fall off the Chilean coast. In other species of genus Epigonus, distributed in the southern hemisphere, such as E. telescopus, spawning occurs during fall and winter in the New Zealand coast (Field et al., 1997).

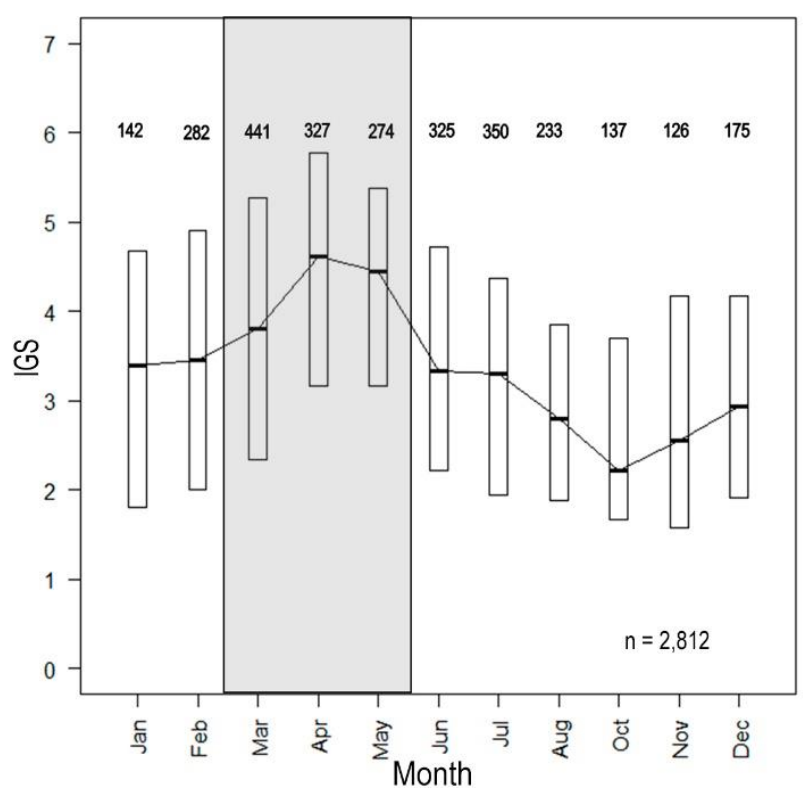

Figure 2. Boxplot of monthly variation of gonadosomatic index (IGS) of Epigonus crassicaudus (females). The black line represents the mean value, and the gray rectangle identifies months of maximum sexual activity for the period 2012-2015. The number of samples analyzed is indicated in the monthly bars.

In studies related to the maturity process in size or age, it is common to find $100 \%$ of mature individuals after a certain length or age. To E. crassicaudus, Flores et al. (2015), based on histological analysis of ovaries, determined $100 \%$ of mature females occurred about 28 $\mathrm{cm}$ FL. In the present study, after $28 \mathrm{~cm}$ FL, some portion of females continued being assigned to the immature fraction of the population, which is frequent in macroscopic scales of maturity because mature adult females in resting, could be mistakenly classified as immature due to its poor ovarian development (Hunter \& Macewicz, 2003; Murua \& Saborido-Rey, 2003; Tomkiewicz et al., 2003; Brown-Peterson et al., 2011). Despite this apparent bias in the allocation of maturity states, $\mathrm{L}_{50 \%}$ reached $22.3 \mathrm{~cm}$ FL close to the value estimated by Flores et al. (2015), who reported an L50\% of $23.2 \mathrm{~cm}$ FL for samples coming from a similar study area. Compared with $\mathrm{L}_{50 \%}$ in technical reports, our results were close to $24.3 \mathrm{~cm}$ FL estimated by Gálvez et al. (2013) and smaller than $32.1 \mathrm{~cm}$ FL, estimated by Cubillos et al. (2009), who considers smaller samples and a more restricted study area.

According to Beverton \& Holt invariants hypothesis (Jensen, 1996), the $\mathrm{L}_{50 \%}$ around 22 or $23 \mathrm{~cm}$ FL agrees with the expected theoretical value for the ratio $\mathrm{L}_{50 \%} / \mathrm{L}_{\infty}$ $=0.67$. If $\mathrm{L}_{\infty}=34 \mathrm{~cm}$ FL, indicated by Moyano et al. (2018), is considered, the value for this relationship in E. crassicaudus would be $\sim 0.65-0.67$. 

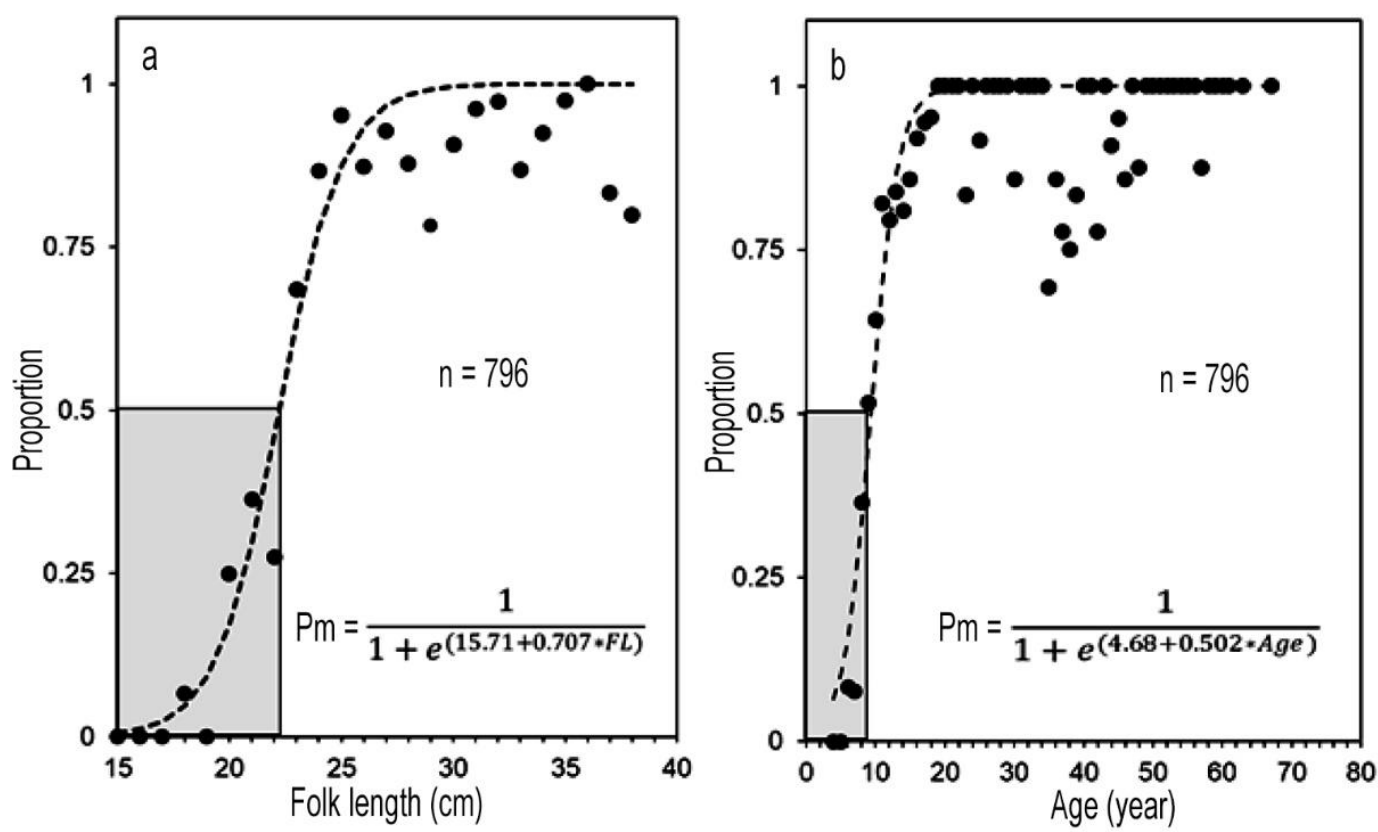

Figure 3. Maturity ogives for the female of Epigonus crassicaudus between 2012 and 2015 in the Chilean coast, in the moths of maximum reproductive activity. a) Length maturity, b) age maturity.

The results for $\mathrm{L}_{50 \%}$ confirmed those reported by Flores et al. (2015), who used the histologic methodology to estimate this value, could validate the macroscopic approach in fish maturity studies when funding is scarce, or a quick estimation is needed.

The estimation of maturity in age is more uncertain in long-lived species (Wilson \& Boehlert, 1990). A correct reading criterion for age allocation is key to an adequate characterization of the maturity process. Unfortunately, no published information was found in order to contrast our results regarding the early age at maturation $\left(\mathrm{A}_{50 \%}=9.3\right.$ years $)$ about the longevity of $E$. crassicaudus (67 years). However, Gálvez et al. (2013), in a technical report, indicated a similar age of maturity (10 years) for this species. Jarić \& Gačić (2012) reported that in long-lived species, there is no linear relationship between $\mathrm{A}_{50 \%}$ and $\mathrm{t}_{\max }$, and consequently, females can mature earlier or later. For example, Tracey et al. (2000) estimated an $\mathrm{A}_{50 \%}$ reached at 35 years for Epigonus telescopus to $\mathrm{t}_{\max }=104$ years. Conversely, Hanselman et al. (2010) reported an $\mathrm{A}_{50 \%}$ of 6.1 years to $t_{\max }=114$ years for Anoplopoma fimbria.

Beyond the criteria used in age assignment, it is known that changes in the life-history traits of fishes are induced by high fishing pressure (Jørgensen \& Fiksen, 2010; Jørgensen \& Holt, 2013). The fishery of E. crassicaudus from 2012 to 2015 removed a high percentage of fish $(\sim 60 \%)$ undersize and age of maturity (Céspedes et al., 2015). This condition could be critical for a deep-water species because of its lower resilience to fishing pressure, with a lower capacity to recover from heavy exploitation than other continental fishes. The model of Jørgensen \& Fiksen (2010) predicted an increase in $\mathrm{M}$ rate as an adaptive response to harvesting pressure. Jørgensen \& Holt (2013) suggest that an increase in $M$ could be part of the explanation for not recovering collapsed stocks.

M can show high variability associated with lifehistory parameters used as input values in indirect methods (Quiroz et al., 2006; Dunn, 2009). In this case, uncertainty was not evaluated, and only two methods associated with age were used. Those methods were implemented because they are usually used to evaluate M in long-lived species (Jarić \& Gačić, 2012). The range to $\mathrm{M}$ in this study $\left(0.06-0.15 \mathrm{yr}^{-1}\right)$ to females of E. crassicaudus includes the value $\left(0.08 \mathrm{yr}^{-1}\right)$ reported by Tascheri \& Flores (2013). Although indirect estimates of $\mathrm{M}$ may contain a high level of uncertainty (Hoenig et al., 2016; Canales et al., 2019), it seems that $\mathrm{M}$ in this research is consistent with the life history characteristics of deep-water fishes with long-live cycle. Tracey et al. (2000), for another member of gender (E. telescopus), reported less value $\left(0.034 \mathrm{yr}^{-1}\right)$, consistent with its expectation life ( $\mathrm{t}_{\max }=104$ years) of the New Zealand coast.

Finally, the life history parameters estimated in the present study could provide an important baseline for future studies, evaluating possible changes on maturity and M. They may also be used in stock assessment 
analysis and to apply effective fishery management measures.

\section{ACKNOWLEDGMENTS}

The authors would like to thank the Fisheries Scientific Observers who collect data overseas, and the Survey Management Department of Instituto de Fomento Pesquero (IFOP), Chile for providing the necessary information for this study. We also thank Mariella Canales for her valuable comments on this research and Francisco Plaza for his help in the manuscript review.

\section{REFERENCES}

Arancibia, H. \& Meléndez, R. 1987. Alimentación de peces concurrentes en la pesquería de Pleuroncodes monodon Milne-Edwards. Investigaciones Pesqueras, 34: 113-129.

Balbontín, F. \& Bravo, R. 1993. Fecundidad, talla de la primera madurez sexual y datos biométricos en la merluza del sur Merluccius australis. Revista de Biología Marina y Oceanografía, 28(1): 111-132.

Brodziak, J., Lanelli, J., Lorenzen, K. \& Methot, R. 2011. Estimating natural mortality in stock assessment applications. Alaska Fisheries Science Center, NOAA Technical Memorandum NMFS-F/SPO-119, 31 pp.

Brown-Peterson, N., Wyanski, D., Saborido-Rey, F., Macewicz, B. \& Lowerre-Barbierie, S. 2011. A standardized terminology for describing reproductive development in fishes. Marine and Coastal Fisheries: Dynamics, Management, and Ecosystem Science, 3: 52-70.

Canales, T.M., Wiff, R., Quiroz, J.C. \& Queirolo, D. Estimation of natural mortality in two demersal squat lobster species off Chile. Journal of the Marine Biology Association of the United Kingdom, 99(7): 1639-1650. doi: 10.1017/S0025315419000717

Cailliet, G. \& Andrews, A. 2010. Age-validated longevity of fishes: its importance for sustainable fisheries. In: Tsukamoto, K., Kawamura, T., Takeuchi, T., Beard Jr., T.D. \& Kaiser, M.J. (Eds.). Fisheries for global welfare and environment, 5th World Fisheries Congress 2008, pp. 103-120.

Céspedes, R., Chong, L., San Juan, R., Gálvez, P., Ojeda, V., Moyano, G., Bravo, R., Muñoz, L., Adasme, L. \& González, J. 2015. Convenio de desempeño 2014. Programa de seguimiento de las pesquerías. Sección V: Recursos de aguas profundas. Instituto de Fomento Pesquero, Valparaíso, 154 pp.

Charnov, E. \& Berrigan, D. 1991. Evolution of life-history patterns in animals with indeterminate growth, particularly fish. Evolutionary Ecology, 5: 63-68.
Clark, W. 1991. Groundfish exploitation rates based on life-history parameters. Canadian Journal of Fisheries and Aquatic Sciences, 48: 734-750.

Cubillos, L., Aguayo, M., Castillo-Jordán, C., Peñailillo, J., Neira, M., Sanhueza, E., Pedraza-García, M. \& Salamanca, M. 2009. Edad, crecimiento y mortalidad natural de besugo. Reporte FIP N²007-36, Universidad de Concepción, Concepción, 153 pp.

Dunn, M.R. 2009. Review and stock assessment of black cardinalfish. Report Fisheries New Zealand (NIWA), $55 \mathrm{pp}$.

Field, K., Tracey, D. \& Clark, M. 1997. A summary of information on, and an assessment of the fishery for, black cardinalfish, Epigonus telescopus (Risso, 1810) (Percoidei: Apogonidae). Technical Report N.Z., Fisheries Assessment Research Document, 97/22: 7 pp.

Flores, A., Wiff, R., Díaz, E. \& Gálvez, P. 2015. Reproductive biology of female cardinalfish, Epigonus crassicaudus de Buen, 1959. Journal of Applied Ichthyology, 31: 718-723. doi: 10.1111/jai.12802

Gálvez, P., Flores, A., Chong, L., Céspedes, R., Ojeda, V., Bravo, R., Moyano, G., Muñoz, L. \& Vidal L. 2013. Asesoría integral para la toma de decisiones en pesca y acuicultura. Actividad 1: seguimiento general de pesquerías de peces y crustáceos: pesquerías demersales y aguas profundas, 2012. Sección VI: Recursos de aguas profundas. Instituto de Fomento Pesquero, Valparaíso, $130 \mathrm{pp}$.

Hanselman, D.H., Lunsford, C.R. \& Rodgveller, C.J. 2010. Assessment of the sablefish stock in Alaska. NPFMC Bering Sea, Aleutian Islands and Gulf of Alaska SAFE, 329-468.

Hewitt, D. \& Hoenig, J. 2005. Comparison of two approaches for estimating natural mortality based on longevity. Fishery Bulletin, 103: 433-437.

Hoenig, J.M., Then, A.Y-H., Babcock, E.A., Hall, N.G., Hewitt, D.A. \& Hesp, S.A. 2016. The logic of 644 comparative life history studies for estimating key parameters, with a focus on natural 645 mortality rate. ICES Journal of Marine Science, 73(10): 2453-2467.

Hunter, J.R. \& Macewicz, B.J. 2003. Improving the accuracy and precision of reproductive information used in fisheries. In: Kjesbu, O.S., Hunter, J.R., Witthames, P.R. (Eds.). Report of the working group on modern approaches to assess maturity and fecundity of warm- and cold-water fish and squids. Institute for Marine Research, Bergen, pp. 57-68.

Jakobsen, T., Fogarty, M., Megrey, A. \& Moksness, E. 2009. Fish reproductive biology: implications for assessment and management. Blackwell Publishing, New Jersey. doi: 10.1002/9781444312133.ch 
Jarić, I. \& Gačić, Z. 2012. Relationship between the longevity and the age at maturity in longlived fish: Rikhter/Efanov's and Hoenig's methods. Fisheries Research, 129-130: 61-63.

Jensen, A. 1996. Beverton and Holt life history invariants result from optimal trade-off of reproduction and survival. Canadian Journal of Fisheries and Aquatic Sciences, 53: 820-822.

Jørgensen, C. \& Fiksen, Ø. 2010. Modeling fishinginduced adaptations and consequences for natural mortality. Canadian Journal of Fisheries and Aquatic Sciences, 67: 1086-1097.

Jørgensen, C. \& Holt, R. 2013. Natural mortality: its ecology, how it shapes fish life histories, and why it may be increased by fishing. Journal of Sea Research, 75: 8-18.

Leal, E., Contreras, F. \& Oyarzún, C. 2009. Distribución, batimetría y alimentación de Epigonus crassicaudus De Buen, 1959 (Perciformes: Epigonidae) en la costa de Chile. Gayana, 73(1): 95-101.

Moyano, G., Cerna, F., Ojeda, V. \& Plaza, G. 2018. Validation of the first annulus and growth model fit for the cardinalfish (Epigonus crassicaudus). Journal of the Marine Biology Association, 99(4): 963-968.

Murua, H. \& Saborido-Rey, F. 2003. Female reproductive strategies of marine fish species of the North Atlantic. Journal of Northwest Atlantic Fisheries Science, 33: 23-31.

Neira, S. \& Arancibia, H. 2004. Comparative analysis of trophic structure of commercial fishery species off central Chile in 1992 and 1998. Ecological Modelling, 172: 233-248.

Nikolsky, G. 1963. The ecology of fishes. Academic Press, London.

Ojeda, V., Wiff, R., Labrín, C. \& Contreras, F. 2010. La longevidad del besugo Epigonus crassicaudus en Chile: ¿es similar a la de sus parientes? Revista de Biología Marina y Oceanografía, 45: 507-511.

Okamoto, M. \& Motomura, H. 2011. Epigonus carbonarius, a new species of deepwater cardinalfish (Perciformes: Epigonidae) from the Marquesas Islands, with a redefinition of the Epigonus oligolepis group. Journal of Applied Ichthyology, 58: 155-160.

Okamoto, M., Motomura, H. \& Asahida, M. 2011. redescription of a poorly known deepwater cardinalfish, Epigonus affinis (Actinopterygii: Perci-formes: Epigonidae), and comparison with related species. Species Diversity, 16: 85-92.

Quiroz, J.C., Wiff, R. \& Caneco, B. 2010. Incorporating uncertainty into estimation of natural mortality for two species of Rajidae fished in Chile. Fisheries Research, 102(3): 297-304.
Reynolds, J., Dulvy, N., Goodwin, N. \& Hutchings, J. 2005. Biology of extinction risk in marine fishes. Proceedings of the Royal Society B: Biological Sciences, 272: 2337-2344.

Rikhter, V. \& Efanov, V. 1976. On one of the approaches to the estimation of natural mortality of fish populations. International Commission for the Northwest Atlantic Fisheries. Research Document, 76/VI/8: 1-12.

Roa, R., Ernst, B. \& Tapia, F. 1999. Estimation of size at sexual maturity: an evaluation of analytical and resampling procedures. Fishery Bulletin, 97: 570-580.

Rose, K., Cowan, J., Winemiller, K., Myers, R. \& Hilborn, R. 2002. Compensatory density dependence in fish populations: importance, controversy, understanding and prognosis. Fish and Fisheries, 2: 293-327. doi: 10.1046/j.1467-2960.2001.00056.x

Schnute, J. \& Richards, L. 1990. A unified approach to the analysis of fish growth, maturity, and survivorship data. Canadian Journal of Fisheries and Aquatic Sciences, 47: 24-40.

Sepúlveda, F., Gálvez, P., Molina-Burgos, B., Meléndez, R. \& Klarian, S. 2018. Hábitos alimentarios del besugo Epigonus crassicaudus combinando contenido estomacal e isótopos estables. Revista de Biología Marina y Oceanografía, 53: 31-37.

Servicio Nacional de Pesca (SERNAPESCA). 2000. Anuario de desembarque total por especie y mes. Servicio Nacional de Pesca, Valparaíso.

Subsecretaría de Pesca (SUBPESCA). 2016. Veda alfonsino, besugo y orange roughy. Ministerio de Economía, Fomento y Turismo, Subsecretaría de Pesca, Decreto Exento N`23 (2016-2020), 2 pp.

Tascheri, R. \& Flores, A. 2013. Estatus y posibilidad de explotación biológicamente sustentable de los principales recursos pesqueros nacionales, año 2012. Besugo. Segundo informe. Instituto de Fomento Pesquero, Valparaíso, $51 \mathrm{pp}$.

Tomkiewicz, J., Tybjerg, L. \& Jesperson, A. 2003. Micro and macroscopic characteristics to stage gonadal maturation of female Baltic cod. Journal of Fish Biology, 62: 253-275.

Tracey, D., George, K. \& Gilbert, D. 2000. Estimation of age and growth, and mortality parameters of black cardinalfish (Epigonus telescopus) in QMA 2 (East North Island). New Zealand Fisheries Assessment Report, 27: $21 \mathrm{pp}$.

Wang, Y. \& Ellis, N. 2004. Maximum likelihood estimation of mortality and growth with individual variability from multiple length-frequency data. Fishery Bulletin, 103: 380-391. 
Wiff, R., Quiroz, J., Tascheri, R. \& Contreras, F. 2005. Effect of fishing tactics on the standardization of cardinalfish (Epigonus crassicaudus) catch rates in the demersal multispecies fishery off central Chile. Ciencias Marinas, 34: 143-154.

Wilson, C. \& Boehlert, G. 1990. The effects of different otolith ageing techniques on estimates of growth and mortality for the splitnose rockfish, Sebastes diploproa, and canary rockfish, Sebastes pinniger. California Fish and Game, 76: 146-160.

Received: 10 January 2019; Accepted: 2 September 2019
Winker, H., Weyl, O., Booth, A. \& Ellender, B. 2011. Life history and population dynamics of invasive common carp, Cyprinus carpio, within a large turbid African impoundment. Marine and Freshwater Research, 62: 1270-1280. doi: 10.1071/MF11054

Ziegler, P., Lyle, J., Haddon, M. \& Ewing, G. 2007. Rapid changes in life-history characteristics of a long-lived temperate reef fish. Marine and Freshwater Research, 58: 1096-1107. 